\title{
LA POESÍA DE DOMINGO LÓPEZ TORRES: HACIA EL SURREALISMO EN CANARIAS
}

\author{
José Ismael Gutiérrez
}

\begin{abstract}
RESUMEN
A causa de su militancia en el partido socialista, el poeta canario Domingo López Torres (1910-1937) murió asesinado en los inicios de la Guerra Civil española tras permanecer varios meses en prisión. Su compromiso no sólo fue político, sino también literario. Enemigo de todo tradicionalismo, simpatizó con aquellas tendencias estéticas renovadoras que incorporaban los estilos, las ideas y conductas más progresistas de la Europa de los años 30, llegando a desempeñar un papel vital en el proceso de recepción del surrealismo en la isla de Tenerife. Este artículo describe el paulatino acercamiento de López Torres al movimiento vanguardista liderado por André Breton. Con ese objetivo se analizan sus dos obras fundamentales: Diario de un sol de verano y Lo imprevisto, ambas inéditas hasta 1987 y 1981, respectivamente. Mientras el primer volumen, escrito hacia 1929, conecta con los principios del Ultraísmo, con el regionalismo postulado por su paisano Pedro García Cabrera, con la "poesía pura” de Juan Ramón Jiménez o con las facetas neopopulistas de García Lorca y de Alberti, el segundo, compuesto en la cárcel de Fyffes poco antes de morir, revela ya el uso de imágenes y procedimientos abiertamente surrealistas.

Palabras clave: poesía, Surrealismo, literatura canaria, López Torres-Domingo.
\end{abstract}

\begin{abstract}
Because of his political afiliation to the Socialist Party, the Canarian poet Domingo López Torres (1910-1937) was murdered in the beginnings of the Civil War after spending some months imprisonned. His compromise was not only political but also literary. Being an enemy of every type of tradicionalism, he sympathized with those renovative aesthetical tendencies that wanted to introduce the most progressist styles, ideas and conducts of 1930s Europe, which made him crucial in the process of reception of Surrealism in the island of Tenerife. This article describes López Torres' gradual approach to the avant-garde movement led by André Breton. His two main works are analized with this aim: Diario de un sol de verano and Lo imprevisto, both inedit until 1987 and 1981 respectively. While the first volume, written around 1928, connects with the principles of Ultraism, with the Regionalism proposed by his fellow countryman Pedro García Cabrera, with Juan Ramón Jimenez's "Pure Poetry" or with Lorca's and Alberti's neopopulist facets, the second one, composed in the prison of Fyffes, just before he died, reveals the use of openly surrealistic procedures and images.
\end{abstract}

Key words: poetry, Surrealism, Canarian literature, López Torres-Domingo.

Dr. José Ismael Gutiérrez. Profesor. Universidad de Las Palmas de Gran Canaria. Correo electrónico: jgutierrez@dfe.ulpgc.es

Recepción: 06- 08- 2010

Aceptación: 20- 08- 2010 
[...] que el claro rumor de su poesía sirva para resaltar el oscuro alarido de su muerte.

Pedro García Cabrera

Expresó Domingo Pérez Minik en 1968 que "vivir en las Islas es una condenación y una felicidad, un purgatorio y un paraíso" (2004a: 50). El árbol del bien y el árbol del mal. Encadenados al doble sino del insularismo, muchos creadores del archipiélago canario han tenido que bregar no sólo con la ensoñación, la autocomplacencia o el sosiego, sino con la miopía, la incomprensión o la indiferencia de propios y extraños. Eso es lo que le sucedió a Domingo López Torres tanto por el lugar en el que nació como por las tensiones a las que tuvo que enfrentarse en un momento convulso de la historia de España. Después de una vida dedicada a la literatura y tras su lanzamiento al mar un aciago día de febrero de 1937, su cuerpo aún palpitante se sumió en el mar para siempre. No en el mar mitológico que cantara el modernista Tomás Morales en las exaltadas estrofas de Las rosas de Hércules, ni en ese otro puerto franco por el que han penetrado las múltiples sugestiones -literarias, culturales, ideológicas- llegadas del exterior, la ruta de encrucijada que el mismo poeta denominó "mar de la cultura" (1993: 206). A López Torres se lo tragó otro monstruo: el mar de la vergüenza, el de la cobardía, el del crimen, las profundas aguas del olvido. De esta zafia manera quedó truncada, además de una existencia que declinó antes de madurar, la prometedora labor artística de uno de los adalides poéticos del surrealismo en Canarias, cuyas enseñanzas, aprehendidas dinámicamente a partir de sus fuentes directas, empezó a dar sus primeros frutos allá por los años treinta del siglo pasado. Su corta estancia en el reino de los vivos no le impidió al poeta tinerfeño desempeñar un significativo papel en la recepción de las teorías bretonianas en el archipiélago -como lo demuestran sus ensayos críticos sobre el tema publicados en Gaceta de Arte, La Tarde y La Prensa-, pese a lo cual su escritura permanecería inédita, esparcida en los medios periodísticos locales, proscrita durante décadas de censura franquista. Su protagonismo en la primera línea de este movimiento vanguardista sólo comenzó a revisibilizarse tras el restablecimiento de los derechos democráticos en España (años setenta y ochenta). Nilo Palenzuela ha indicado que la desaparición de López Torres fue doble: por un lado, el rumor de su voz poética quedó sellado con su asesinato; por el otro, el posterior ejercicio de borrón y cuenta nueva que impuso la dictadura fascista en todos los órdenes de la vida nacional acabó por estigmatizar su recuerdo (1997: 189).

El surrealismo fructificó en Canarias en el quehacer de un cenáculo de jóvenes devotos que la crítica nacional e internacional ignoró por mucho tiempo. El estudio de 1972 Surrealism and Spain, de C. B. Morris, fue uno de los primeros en enmarcar la contribución de los autores isleños en las coordenadas española y francesa del movimiento: "El surrealismo encontró sus defensores españoles más entusiastas e ilustrados en Eduardo Westerdahl, Agustín Espinosa, Pedro García Cabrera, Domingo López Torres y Domingo Pérez Minik" (Morris 2000: 54). El penúltimo de ellos compendió la deuda de los surrealistas con Freud, revisó su literatura, aquilató la levadura noética de sus artífices interpretando sus fórmulas desde el aquí y el ahora. Pero esa fiesta terminó por aguarla la Guerra Civil. La súbita detención del poeta en los albores del acontecimiento bélico por su actividad sindicalista y su militancia política izquierdista, su encierro en un antiguo almacén de plátanos, propiedad de la empresa exportadora inglesa Fyffes -reconvertido para la ocasión en mísera cárcel a la que iban a parar los adversarios de la Falange- y, por último, su homicidio unos meses 
después a manos de las siniestras tropas antirrepublicanas asentadas en la isla dejó un vacío inestimable en el activísimo panorama de la poesía canaria anterior a la contienda. Con distintas matizaciones, algo similar ocurriría con otras bajas literarias en la Península Ibérica: la de García Lorca, fusilado por reaccionarios, envidiosos y enemigos de su familia, o la muerte de Miguel Hernández en una lóbrega prisión alicantina en la que enfermó de bronquitis, tifus y tuberculosis, todos víctimas de la "energía demoníaca” que desencadenó el fascismo (Paxton 2005: 150). Los abusos del poder y los designios de la política han atribulado especialmente a los artistas. Con la muerte del poeta canario, la próspera continuidad del hormigueo creativo gestado al calor de las corrientes de la modernidad artístico-literaria europea y que durante más de una década llevaba forjándose en las Islas quedó en suspenso. Inexcusable en el proceso internacionalista de la cultura insular de esos años fue la impronta dejada por la escuela que encabezó Breton, emisario de unas propuestas que tuvieron su caldo de cultivo en Francia pero que enseguida se propagaron por otras latitudes, incluyendo las Islas Afortunadas, donde las condiciones geográficas del archipiélago les dieron una proyección algo limitada, sin ser por ello un fenómeno marginal ni ultraperiférico, como han considerado algunos, pues el surrealismo fue ante todo un movimiento apátrida y policéntrico que se extendió por diferentes contextos nacionales (Pérez Corrales 2006: 19). Si pensamos que la filosofía y las técnicas surrealistas fueron interceptadas en las islas en su lengua original ${ }^{1}$ y que sus productos acabarían por alcanzar rasgos de una singularidad pasmosa equiparable a la lograda en el continente, poco crédito habría que concederles a los que lo han reducido a unos pocos nombres señeros y a un núcleo estrictamente francés. Las expresiones libertarias de la fiebre surrealista, con su avalancha de imágenes inconexas y absurdas, con su dialéctica del materialismo histórico y su pasión por lo onírico, obtuvo en tierras insulares momentos clave y gloriosos de los que dan buena cuenta las obras de Pedro García Cabrera -Entre la guerra y tú, Dársena con despertadores, ambas de 1936-, de Emeterio Gutiérrez Albelo - Romanticismo y cuenta nueva (1933) y Enigma del invitado (1936) - o de Agustín Espinosa -Crimen (1934)-.

De esta última novela, se encargó de resaltar López Torres, entre otros hallazgos, su autenticidad, la espontaneidad de su estructura compositiva y su función epatante e inconformista al embestir contra la hipocresía social y contra la estupidez del ambiente circundante. Con sus obscenidades y escenas macabras, Crimen contravenía la perspectiva de los sectores más conservadores de la crítica literaria y de los poderes fácticos dominantes, motivo por el cual fue tantas veces vilipendiada (López Torres 1993: 2000)².

Pero 1937 no fue sólo el año de la desaparición de López Torres, el año de la disgregación completa del movimiento surrealista tinerfeño; también fue aquel en el que se recrudecieron las iras que levantarán un muro de contención al vendaval de libérrima iconoclasia que impulsaron las efervescentes tendencias estéticas, lo que supondría un serio estancamiento para el desarrollo económico de España y de su cultura hasta entonces de signo progresista. Sin embargo, el bloqueo en el que quedó inmerso el país y sus colonias atlánticas venía incubándose desde 1936 cuando pareció ya irreversible el estallido de la insurgencia armada que iba a mantener a la sociedad civil española dividida en dos frentes contrapuestos. La eclosión de la guerra fraticida en la que se enzarzaron falangistas y republicanos cercenó de un tajo la atmósfera de entusiasta creatividad desarrollada tras la dictadura de Primo de Rivera (1923-1930), reemplazada luego por otra etapa más oscura, monolítica e inquisitorial en la que el miedo, el totalitarismo y la mentalidad cerril comenzaron a enseñorearse de las voluntades. Por 
lo tanto, desde un punto de vista literario, el inicio de la contienda implicó el cese "del proceso público de la vanguardia histórica en Canarias” (Sánchez Robayna 1992: 8), más concretamente, de la primera oleada surrealista, que continuó, no obstante, fraguándose a la sombra.

En 1936 dejaron de editarse revistas de avanzada como Gaceta de Arte y la impresión de libros se colapsó; los escritores abandonaron su labor, voluntariamente o por la fuerza, para ocultarse en sus guaridas o "travestirse" en meras comparsas de la cultura oficializada, mientras el rugido contestatario de su clamor fue asordándose al paso de los bombardeos asesinos o sucumbiendo bajo el peso de un montón de ruinas circulares. Las conversiones doctrinales, el destierro del escritor del lar que lo vio nacer, la soledad de la mazmorra, los fusilamientos improvisados a medianoche y la condena deletérea del mar, siempre el mar -y más en unas islas como las del archipiélago canario, inmóviles, solitarias y circundadas de agua por todas partes, ese piélago que lo connota todo, lo mismo vida que muerte, igual cárcel que trampolín a lo desconocido- serán inminentes destinos que lo abocarán inopinadamente al desastre.

Para López Torres, como para otros muchos poetas de cualquier época y nacionalidad, el mar tuvo valores ambivalentes. Fue introversión y esparcimiento, ensueño e inquietud, principio y desenlace, prisión y fuga, regazo materno y tumba. También encarnó un espacio de intercambio y de enriquecimiento dialógico posible con el "otro", ya fuera colono, inmigrante, turista o visitante, el lugar utópico por excelencia por el que ingresarían desde otras geografías la crítica intensa, el debate, el aluvión de relaciones culturales, de ideas, de formas innovadoras o de modas que amarraron sus anclas en la pequeña ciudad de provincias que era aún a finales de los años veinte y comienzos del treinta la capital tinerfeña. Poco hacía sospechar que, vislumbrándose lejano el erial de la vejez, el mar acudiría pronto a tragárselo, aun cuando el accidente de barca que precediera a este último hecho luctuoso en la bahía del puerto de Santa Cruz de Tenerife -y del que milagrosamente salió ileso- venía anticipar que el océano sería su postrera morada. Esta segunda vez - contaba entonces veintisiete años- no correría con la misma suerte que tuvo en $1930 \mathrm{y}$, sin embargo, nuestro escritor no fue tanto víctima circunstancial de un mar encolerizado y caprichoso como chivo expiatorio de la barbarie, de una de esas muchas corrientes de irracionalidad que de tanto en tanto ensombrecen la historia político-cultural de los pueblos.

Nacido en 1910, irrumpió López Torres en la escena literaria a temprana edad (la precocidad fue una ventaja que compartiría con otros miembros de la vanguardia canaria). Sus primeras incursiones literarias, los poemas "Tus ojos glaucos", soneto que recrea el estereotipo de la femme fatale, "Cuando se marcha..." y "En el puerto" -el primero de 1926 (contaba el autor entonces dieciséis años), y los dos restantes de 1928-, prolongan la fecunda estela del modernismo en lengua española. "Tus ojos glaucos..." y "En el puerto" se publicaron en la revista semanal Hespérides ${ }^{3}$, cuyas páginas, dirigidas por el omnipresente Rafael Peña León, aglutinaban una hornada de autores de diferentes edades con los que departió López Torres en ese dorado paréntesis de entrenamiento, mientras que la segunda composición, "Cuando se marcha...", vio la luz en el diario santacrucero El Progreso 4 . Dos años más tarde -intervalo al que talvez pertenezcan algunas de sus composiciones poéticas sin datar o publicadas más adelante en Gaceta de Arte-, su nombre comienza a afianzarse en los circuitos literarios isleños. A la vez que sigue escribiendo en la prensa -labor que nunca va a abandonar-, establece nuevas relaciones de amistad y además participa de forma activa en revistas estéticamente comprometidas. En medio de estas precoces aventuras intelectuales, aún tuvo tiempo para esbozar los poemas y fragmentos de prosa poética que integrarán su 
Diario de un sol de verano, compilación de textos breves marcados por el sesgo insularista, centrados en lo autóctono y en lo receptivo ante la fascinación de la extrañeza cotidiana. Se trata de un testimonio donde anida la memoria de un poeta y de una época que capturan oblicuamente la aventura mágica de la estrella principal de nuestro sistema planetario (el sol) cuyo latir y devaneos proponen una cálida trayectoria antes de que su ocaso y de que el odio, con su maquinaria destructora, lancen los temibles tentáculos que sumirán en una neblina total cualquier manifestación de hedonismo, de inocencia, de intensidad física o espiritual que incentive los ánimos. Apto para nostálgicos impenitentes de dichas actualizadas, para los que aún presuponen la belleza de la sencillez en oposición a lo hermético o neobarroco o que creen en la genialidad de lo inmaduro en vez de en una obra de factura bien acabada o en una poesía que camine ciegamente hacia un futuro sin nubarrones, Diario de un sol de verano trata de unificar sin contradicción lo cercano y lo exótico, la visión de lo regional y el espíritu universalista.

Estamos en 1930. Conocedor ya de algunos de los experimentos realizados por la literatura de las primeras vanguardias (ultraísmo, futurismo, dadaísmo...), fundó, junto a sus compañeros José Antonio Rojas, Julio Antonio de la Rosa, Pedro García Cabrera y Juan Ismael -los "cuatro cazadores de estrellas marinas", como se autodenominaron algunos de ellos años atrás ${ }^{5}$ - Cartones, modesta revista donde la isla adquiría perfiles netos de afirmación, al decir de Domingo Pérez Minik (1995: 221) y cuyo único número -soliviantado por el encuentro entre los poetas tinerfeños de aquella hora y los pintores de la Escuela "Luján Pérez" de Las Palmas de Gran Canaria, que expusieron sus cuadros en Tenerife en junio de ese mismo año (cfr. Palenzuela 1992: 29)- recogía dos breves textos englobados bajo el título genérico de "Olas". Dichos poemitas terminarán alojándose posteriormente bajo las enumeraciones 9 y 26 en el mencionado Diario de un sol de verano ${ }^{6}$. Miguel Martinón, entre otros investigadores, ha subrayado cómo Cartones compatibiliza dos miradas distintas:

\footnotetext{
Los animadores de esta publicación se empeñaron en definir una poética insular, que se proponía distanciarse de cualquier estética regionalista y situar su creación bajo el signo universal de la literatura y el arte moderno. Pero, al mismo tiempo, aquellos jóvenes defendían una práctica creadora que hundiera sus raíces en los hechos característicos de la historia y la naturaleza de las Islas. (Martinón 1996b: 106)
}

Esa bifronte declaración de principios apenas tuvo oportunidad de dilatarse, ya sea por culpa de la corta vida de Cartones, ya por la mediocridad del medio, o bien por falta de recursos económicos o la inesperada muerte de dos de sus jóvenes animadores (Julio Antonio de la Rosa y José Antonio Rojas, que perecieron ahogados en el mismo accidente de barca que también sufriera López Torres). Por lo demás, no debe extrañarnos la rápida extinción de la revista, ya que el carácter efímero, signo inequívoco de los tiempos modernos, según Baudelaire (1995: 43-4), impregnaría el devenir de muchas de las publicaciones periódicas literarias del período vanguardista cubriéndolas de una pátina fugitiva, de una transitoriedad congénita que se convertirá en cédula identitaria de estos órganos manifestarios y de divulgación, destino del que no se librará tampoco la siguiente empresa colectiva promovida por la vanguardia tinerfeña: la revista Índice, encabezada igualmente por López Torres. A diferencia de Cartones, Índice fue más una publicación combativa y de acción que de formato propiamente literario, pero lo mismo que aquélla, no gozó de especial longevidad, siendo otro de esos meteoritos que velozmente cruzó el estrellado cielo tinerfeño sin llegar a sentar plaza en el adormecido contexto al que iba dirigido: carente de savia sostenible, languideció tras una primera entrega, la de marzo de 1935. 
Más trascendente en sus conquistas que estas dos, y objeto de numerosas aproximaciones críticas, sería la publicación que naciera tres años antes -la mítica Gaceta de Arte-, que sí logró conmocionar las sensibilidades tradicionalistas, ampliando el abanico de expresiones artísticas españolas y sacudiendo de su modorra habitual a la poesía del entorno canario. Gaceta de Arte es considerada actualmente el mejor órgano difusor de las corrientes modernas de procedencia extranjera en las islas y, sin duda, una de las más destacadas del país. Apostó por la innovación dentro de una línea ecléctica, y emprendió una tarea de abastecimiento en la que se dio cabida al surrealismo, pero sin darle absoluta exclusividad (cfr. Pérez Corrales 1982: 669)7 ${ }^{7}$. Las coincidencias de Gaceta de Arte con el surrealismo generado en la tramontana residían más en la común intencionalidad de desbancar fórmulas periclitadas, en el combate hacia el absolutismo ideológico y en la aversión hacia la impermeabilidad mental que en la simple obediencia a un programa estético uniforme: el "fondo anticapitalista y universal, su voluntad de destrucción de la sociedad burguesa y de las instituciones decorativas que combaten y destruyen todo acto libre" (Pérez Minik 1995: 89) fueron sus principales divisas. El idilio de López Torres con semejante credo se remonta a los primeros años de la década del treinta (finales de 1932) cuando la publicación literaria se aventuró a dar la bienvenida a un arte que, surgido en 1916, empezaría a tomar cuerpo hacia 1924, cuando Breton difundió el primer manifiesto teórico de la corriente. Entre ese año cenital y 1935, López Torres publicitó diversos aspectos de este movimiento de vanguardia en lúcidos artículos aparecidos no sólo en ésta su revista de cabecera, sino en los diarios La Prensa y La Tarde: "Surrealismo y revolución" (1932), "Psicogeología del surrealismo” (1933), “QQué es el surrealismo?” (1933), “El surrealismo” (1933), “Aureola o estigma del surrealismo" (1933), "Índice de publicaciones surrealistas en 1934” (1934), "Una cruzada internacional de arte surrealista" (1935) o " 1 a exposición colectiva de arte surrealista" (1935) son algunos de esos títulos. En la segunda mitad de 1935, por otro lado, la publicación tinerfeña acogió entre sus páginas las primeras traducciones de Paul Éluard, de André Breton, de Hans Arp y de Benjamin Péret.

Hay que destacar que en el cuaderno de bitácora del movimiento en tierras tinerfeñas ocuparía un lugar preferente la exposición, organizada por el grupo de redactores de la Gaceta de Arte, de las pinturas de Óscar Domínguez, artista canario afincado en París desde $1927^{8}$. La sugestiva figura de Óscar Domínguez -a través de su relación epistolar con los artistas vernáculos y sus continuos viajes de ida y vuelta desde Tenerife a París o a la inversa- sirvió de hilo conductor entre éstos y la actividad de los vanguardistas franceses. El padre de la decalcomanía fue, en opinión de Pérez Minik (1995: 159), "nuestro mejor amigo en París", una afirmación que con la perspectiva de los años ha ido adquiriendo carácter de verdad incuestionable. Por eso, la celebración de la muestra pictórica en el Círculo de Bellas Artes de Santa Cruz de Tenerife, entre el 4 y el 15 de mayo de 1933, y posteriormente en Las Palmas de Gran Canaria, tuvo tal relevancia. Sin duda significó un hito fundacional en la preparación del terreno para el florecimiento ulterior de la intención heterodoxa, el antiacademicismo artístico y la subversión ligada al surrealismo ${ }^{9}$. López Torres no se quedó al margen del deslumbramiento vanguardista. El 10 de mayo de 1933 publicó un artículo en el cual escribía que la pintura de Domínguez conseguía un equilibrio entre el abigarramiento desmesurado, onírico de la técnica daliniana y la delicada simplicidad de las obras de Joan Miró. En esta misma reseña, y en otra que viera la luz en la prensa siete días después, emparentó las creaciones de su paisano, colmadas de referencias mágicas, mecanicistas y sexuales, con el auténtico sello surrealista. Sus lienzos discurrían por "las turbias aguas de 
la psiquis", agrupaban figuras, objetos y elementos de tonalidades y transparencias insólitas presididos todos por una fantasía exuberante e imágenes que parecían brotar del rico laberinto de los complejos sexuales en el que habían escudriñado las teorías del psicoanálisis freudiano décadas antes. Esta manera de afrontar el arte haciéndolo conciliar con los fenómenos de la mente no se distanciaba un ápice de los métodos afines al surrealismo: "El artista surrealista deja libre paso a la espontánea expresión del subconsciente haciendo de medium de sí mismo, atrapando desde las más altas ventanas los más bajos paisajes del espíritu" (López Torres 1993: 154) ${ }^{10}$.

Si bien por esas fechas López Torres era un poeta de obra íntegramente inédita-siempre lo seguirá siendo en realidad, pues los contados poemas que dio a conocer se hallan diseminados en publicaciones periódicas de su tierra, sin llegar a conformar un libro homogéneo-, su nombre debió ya de resultar familiar en los círculos bretonianos extrainsulares, ya que también en el treinta y tres Paul Éluard y el mismo Breton, dos de los iconos responsables del huracán artístico subversivo que arrasará con los demás "ismos" precedentes y cuyas osadías "[rompían] violentamente con todo lo que se [oponía] a la natural expresión del subconsciente" (López Torres 1993: 134), lo invitaron a él (y al escritor madrileño Ernesto Giménez Caballero, dos años después trasformado en declarado fascista) a participar en una encuesta de la revista francesa Minotaure. En dicha encuesta no se le preguntó, como hubiese sido lo normal, por su quehacer literario ni por su opinión sobre la tendencia surrealista a la que él ya rendía pleitesía, sino por aquel incidente de su vida que lo había marcado íntimamente. A la consulta López Torres contestó rememorando la voluptuosidad sexual que le produjo la lectura, a la edad de nueve años, de un libro sobre matrimonio e higiene, un libro técnico que, con la inocencia típica de la niñez, él devoró como si de pura pornografía se tratase: "Desde entonces, comencé a ver y a comprender todo un mundo de sexualidad con tal impetuosidad que ni el mar ni las playas de mi isla, donde entretenía la inquietud de mis veinticinco años, pudieron calmar mis ardores" (López Torres 1993: 229). Al autodescubrimiento de su emergente sexualidad le ayudaría también, aunque de otra manera, el ímpetu irreverente del surrealismo.

Sin embargo, el diálogo poético e intelectual con el máximo pontífice de la escuela tomaría forma real dos años más tarde con la llegada del poeta francés a Tenerife, acompañado de su esposa Jacqueline Lamba y de otro representante del movimiento, Benjamin Péret, que por entonces aún no había producido lo mejor de sí como poeta. La excusa fue la "Segunda Exposición Internacional del Surrealismo", que el mismo López Torres, junto a sus colegas de Gaceta de Arte, organizó en 1935 en la capital santacrucera ${ }^{11}$.

En los artículos escritos a raíz de este evento y estampados en la prensa capitalina, López Torres comparó esta celebración con una cruzada internacional, con una especie de misión evangélica o de campaña proselitista que colocaría a la distante isla de Tenerife en el punto de mira de la intelectualidad extranjera, junto a ciudades tan cultas como París, Belgrado, Copenhague, Bruselas, Zurich, Londres, Nueva York o Tokio. Unas pocas fotografías conservadas atestiguan la presencia de López Torres en compañía de Breton, Jacqueline y Péret en las distintas actividades desarrolladas para la ocasión y en algún que otro paseo por los rincones de la isla ${ }^{12}$. Es casi seguro que fue el mismo López Torres quien le hizo al autor de Nadja la entrevista (fechada en mayo de 1935) que constituirá la célula embrionaria de la Déclaration redactada entonces en francés y en español que apareció en octubre de ese mismo año en el número 2 del Bulletin Internacional du Surréalisme, manifiesto firmado por el propio López Torres, por sus compañeros de Gaceta de Arte y por Breton y Péret. 
López Torres no vaciló en incorporarse al proyecto de Gaceta de Arte desde un primer momento. El autor de Lo imprevisto, junto a otros cinco jóvenes inquietos, participó como redactor y asiduo colaborador, dividiéndose su tarea entre la transmisión de poemas propios de renovada factura ("Torero, pasión y muerte", "Picasso", "Aquella enorme plaga" y "Poema de la langosta", a medio camino entre la estética de 1927 y los ingredientes transgresores de corte surrealista) y la difusión entre sus coetáneos de los fundamentos teóricos del reverenciado movimiento que animaba incansablemente Breton desde su atalaya parisina y del que él ya se sentía partícipe. Este movimiento llegó a esas islas tras poner patas arriba los saberes conceptuales establecidos en una inestable Europa que vivía con celeridad y asombro el período de entreguerras:

\footnotetext{
Nace [...] el surrealismo de una necesidad grande revolucionaria de destrucción que arruinará definitivamente los conceptos de familia, patria, religión. Necesidad apremiante para poder construir el espíritu de la moderna juventud. Romper con todos los prejuicios de una civilización caduca; desescombrar a la humanidad de una cultura gastada; desacreditarla, arrastrar por las calles las galas de la burguesía. Porque para el surrealismo no hay más realidad que la realidad interior, la verdadera expresión personal libre de toda conveniencia social, de todo control razonado, de toda dictadura moral. (López Torres 1993: 1953)
}

La ideología surrealista renegó a ultranza de los intereses de la sociedad burguesa, del decadente sistema capitalista y de cualquier otro dogmatismo filosófico que supusiera trabas insalvables a la búsqueda de la libertad expresiva, relativizando así la validez funcional del arte anterior y los empobrecedores cánones institucionalizados sobre los que se apoyaba la tradición enquistada. El análisis de las obras resultantes del trabajo de varios artistas internacionales de última hora, algunos de los cuales atravesaban por esas fechas por un estadio más o menos surrealista o habrían de hacerlo muy pronto -George Grosz, Edwin Piscator, Salvador Dalí, Hans Tombrock, Pablo Picasso o Hans Arp, entre otros ${ }^{13}$ - confirma lo bien informado que ya estaba entonces el poeta tinerfeño de todo cuanto acontecía a su alrededor, incluyendo aquellas concepciones artísticas más rompedoras.

Sin embargo, su radicalismo resulta más fácilmente perceptible antes en sus ensayos que en su poesía, porque la obra poética de López Torres, que no se asomaría a los abismos surrealistas hasta poco antes de su fallecimiento, aún andaba por otros derroteros: ese purismo y neopopulismo que será rasgo común en varios títulos del mismo período (Índice de las horas felices de Félix Delgado (1927), Líquenes de García Cabrera (1928), Campanario de la primavera de Gutiérrez Albelo (1930) o el póstumo Tratado de las tardes nuevas de Julio Antonio de la Rosa (1931)). Por razones obvias, López Torres no contó con el tiempo suficiente para culminar la rebelde empresa poética labrada bajo el dios tutelar del surrealismo. La evolución de su estética, al quedar interrumpida, no llevó hasta sus últimas consecuencias las enseñanzas que había procesado desde el año treinta y dos ni obtuvo una madurez semejante a la de otros poetas de su misma generación que sí habrían de gozar de una existencia más dilatada. Con todo, al enfrentarnos al breve legado textual de López Torres, podemos trazar un arco que apunta una andadura ascendente hacia las metas surrealistas, aunque sin excesivos alardes. En su obra. se observan tres instantes poéticos que, fugaz y transitoriamente, completan su proceso creativo: una primera etapa modernista, seguida de otra de linaje purista y neopopulista que desembocará en otra de abolengo incipientemente surrealista. Del modernismo tardío -o posmodernismo- en que debuta en 1926, un posmodernismo anclado aún en estilos poéticos devenidos en clichés, en formas de enorme colorismo léxico y ocasional ampulosidad verbal, de raigambre descriptiva e intimista, un tanto demodés, pasaría a integrar el círculo de la llamada 
"nueva literatura" tras un paulatino contacto con la experiencia lírica veintisietista (más concretamente influenciada por Rafael Alberti y Federico García Lorca), sin menospreciar el magisterio, casi simultáneo, de la poesía "pura” de Juan Ramón Jiménez, otro de los autores que acabaría por desprenderse de la vacua hojarasca rubendariana de sus primeras obras para acogerse al intelectualismo, a la expresión bruñida o al riguroso y económico uso de la imagen. Con ese viraje orientado a la "inmensa minoría", principio clave de la "generación del 14", Jiménez se alza en un punto intermedio entre la generación de Ortega y Gasset y las vanguardias histórico-artísticas más radicales. El lenguaje de síntesis purista juanramoniano, traducido en una poesía sin artificios, se complementa con la vertiente neopopulista que postulaban otros sectores jóvenes de la escritura lírica peninsular, neopopulismo que López Torres, desde las islas, abrevó de reconocibles fuentes exógenas (los ya citados Alberti y García Lorca, principalmente), aunque en él se tratara de un modo provisional de poetizar que pronto quedará superado en cuanto toma contacto con las experimentaciones de un Paul Éluard y un André Breton, jerarcas del surrealismo. Las doctrinas surrealistas lo van orientando a él poco a poco hacia una hipnótica fulguración expresiva, cuyo agigantado encantamiento, sellan de turbiedad e inquietud interna el cúmulo de asociaciones que espejean en el volumen inconcluso que elaboró López Torres en la prisión de Fyffes en 1936 y que permanecerá desconocido para el gran público durante más de cuarenta años: Lo imprevisto (1981). Este texto se aproxima -al menos en un nivel formal- a los destellos surrealistas, aunque sin llevar hasta límites exagerados los procedimientos del automatismo psíquico (dejar que la mano vaya anotando lo primero que le dicta la cabeza, por incoherente que pueda resultar), sin extremar la asociación libre de palabras y la libertad de la imaginación contra el reinado de la lógica. La expresión se va enmarañando en una obra sin terminar que, al decir de C. B. Morris, "pronostica la sorpresa del lector al manipular un tomo que, destinado a ser un libro-objeto, se despliega para ofrecer a la vista ocho dibujos de índole surrealista hechos por su amigo y compañero de cárcel Luis Ortiz Rosales" (1983: 30), exterminado lo mismo que él por las brigadas del amanecer en la bahía del puerto de la capital tinerfeña. Agrega el mismo crítico que el título vaticina la perplejidad del escritor ante los repentinos cambios sufridos en su isla, donde se ha pasado de una época tolerante, creativa y cosmopolita a otra dominada por la intransigencia, el silenciamiento y la crueldad (1983: 30). Miguel Martinón ha defendido la estirpe surrealista de este breve cuaderno por cuanto indaga "en las vivencias oscuras, absurdas o 'imprevistas' con que se enfrenta Domingo López Torres en las singulares condiciones de la prisión" (1992: 279-280). En ese difícil trance, le debieron servir de estímulo los hallazgos sobre la interpretación de los sueños de Sigmund Freud, el descubrimiento de los secretos almacenados en el subconsciente que reivindicó el científico alemán y sus esclarecedoras investigaciones en torno a la pulsión de los móviles sexuales -sofocados regularmente por la voz censora de la conciencia- en las acciones humanas.

No sería ocioso que contemplemos también esta inclinación a favor del subconsciente registrada en los últimos años de López Torres dentro del marco de los posicionamientos políticos que exhibió el autor, ya que éstos, al fin y al cabo, van a influir en su desgraciado fin. López Torres, a medida que consolidó sus orientaciones estéticas, se sintió cada vez más identificado con la ideología izquierdista, con la causa del proletariado y con un arte al servicio de los estamentos sociales más desfavorecidos. Desde las páginas de El Socialista reclamó para la agricultura canaria eficaces reformas que contribuyeran a paliar el desastroso estado del sector en las islas. En la parcela estética, estuvo de parte de los poetas que, como Vladimir Mayakovski, 
han consagrado su talento a los intereses del pueblo que gemía y vivía esclavizado por el sistema, o elogió a pintores que, a semejanza de George Grosz y Hans Tombrock, mostraban las miserias de una civilización capitalista en descomposición, sin ocultar un severo desdén hacia la burguesía y las instituciones de las que se servía el poder (clero, ejército). Los cultivadores de lo abstracto, los instigadores de un "arte de laboratorio", evadido de los problemas de la vida contemporánea, se doblegaban en cierta medida a los resortes de las clases dominantes. De ahí que en marzo de 1932 confesara cierta decepción ante el estatismo paisajístico e irreal que veía en los cuadros de Juan Ismael, al tiempo que proclamaba la necesidad de una praxis artística más íntimamente supeditada al orden social. En oposición a la tendencia artificiosa en el arte, los únicos autores y artistas plásticos que, a su juicio, merecerían salvarse de la criba son aquellos que abogaban por la sinceridad, esto es, los "que encauzan sus actividades por caminos de lucha, frente a una civilización caduca, hacia nuevos horizontes, poniendo su arte al servicio de una acción colectiva” (López Torres 1993: 127). Esta posición doctrinal de López Torres no fue excepcional en el territorio español ni en el extranjero. Análogamente a sus compañeros literarios en Francia, muchos poetas hispanos comulgaron con los planteamientos del marxismo, del socialismo o simpatizaron con la lucha de clases y con la filosofía del materialismo histórico, además de con el psicoanálisis. Ya Guillermo de Torre advertía en su clásica Historia de las literaturas de vanguardia que mientras el dadaísmo, del cual se desgajó el surrealismo, se quedaba en la broma intrascendente, el movimiento que le sobrevivió tornaba la risa jovial en mueca grave y en protesta que excedía el plano de lo literario para matrimoniarse con lo metafísico, incluso con lo político y social. Al revisar las hojas de La Révolution Surréaliste (1924-1929), percibiría el crítico e historiador de la literatura que en la revista

\footnotetext{
un día es la glorificación de un anarquista; otro el estallido de la fobia anticlerical o antimilitarista; otro la adhesión a la revolución rusa, pero en la representación de un disidente: Trotsky. Si en cierto momento lanzan una hoja contra Claudel, no atacan tanto al literato como al embajador de Francia en China y a la colonización francesa. (2001: 366)
}

El espejismo del comunismo encandiló a un grupo destacado de la intelectualidad de los años veinte: Péret, Breton, Aragon, Éluard, Queneau y Desnos, por citar sólo algunos de los que coincidieron en París por esos años. Guillermo de Torre justificó esa militancia en los siguientes términos:

\footnotetext{
Todavía permanecía deslumbrante el resplandor de octubre de 1917 (mejor dicho, había adquirido nuevo brillo con las amenazas del nazismo y el fascismo) y la revolución rusa no había mostrado aún su verdadero rostro totalitario e implacable, que iban a revelar los primeros "procesos de Moscú". En el campo de las artes, aunque ya asomara la dogmática del "realismo socialista", por un lado los escritores de otros países solían hacerse los distraídos, y por otro aún no había sonado allí la hora del conformismo reaccionario, disfrazado de lo opuesto. (2001: 389)
}

Pero el romance con el comunismo no había de perdurar indefinidamente. Lo que en primera instancia las nuevas generaciones disconformes aceptaron como una ilusión, más que como un dogma, por no haberse solidificado aún, provocará enseguida numerosas reacciones en su contra. La sumisión absoluta a unos principios y métodos que exigía el credo comunista chocaría con el talante del surrealismo, que desconfiaba de la viabilidad de un arte propagandístico y abocado netamente a lo utilitario, lo que explica algunas de las "excomuniones" operadas en las filas de la escuela, como la de Louis Aragon, que terminó aferrándose a las consignas ideológicas soviéticas tras participar en 1931 en un Congreso Internacional de escritores revolucionarios en la URSS. 
Muchas de estas filias y disensiones las acusan decenas de poetas que tanto en Europa como en América enrumbaron el curso de su arte hacia una "poesía del porvenir", pero comprometida con el presente. Y López Torres no dio la espalda a este ambiente de polémica, de vívido engagement. Sin llegar a decretar los abusos del cientificismo marxista que cautivó a algunos de los miembros de la facción surrealista internacional, el joven poeta tinerfeño, que no provenía precisamente de las clases sociales privilegiadas, ya que para sobrevivir tuvo que desempeñar oficios varios como el de dibujante de orfebrería, oficinista en una consigna de buques o librero, pudo ejercer, valiéndose de escasísimos recursos, de articulista y de animador cultural en su ciudad natal, haciendo todo lo que estaba en sus manos para compaginar los postulados radicales del surrealismo más ortodoxo con la crítica antiburguesa explícita en los discursos de Karl Marx y Friedrich Engels. En un denodado empeño por remover la mentalidad del ser humano y contribuir a la formación integral del hombre, López Torres acentuó el estallido surrealista -el "ismo" más evolucionado de cuantos habían surgido a lo largo de la última década- cuyos máximos representantes, que proclamaban su inserción en la vida de los demás hombres, en la vida colectiva, se empapaban del pensamiento comunista y clamaban por un orden revolucionario ${ }^{14}$. Él, por su parte, hizo suyas las corrientes socialistas y antiburguesas. Propia del escritor fue la tentativa de eliminar cualquier hipocresía arraigada en la sociedad - por ejemplo, en el terreno de la sexualidad, de las ideas y del trabajo ${ }^{15}$ - y de fustigar con belleza la injusticia.

Este anhelo de preocupación sociopolítica, es verdad, apenas dejó huellas indelebles en su poesía, por mucho que en otras parcelas de su escritura quedara más que patente. En sus ensayos, espigamos axiomas como: "toda obra de arte - producto de un artista- no es más que obra al servicio de la humanidad con todas sus miserias, vicios y virtudes en este agitarse entre cosas grandiosas y mezquinas que es, en todo caso, vida" (López Torres 1993: 203). O bien la siguiente afirmación: "El arte puro, el arte por el arte, no se concibe, en este siglo en que un fiel indeciso entre capitalismo y socialismo tiene suspenso al mundo" (1993: 117). Y es que, aunque rehuyera de la imagen torremarfilista del artista, hay que incidir en la ambivalente disponibilidad de López Torres hacia la alteridad: si, por un lado, se mostró sensible hacia los problemas de su época (el "yo" y sus circunstancias de los que hablara Ortega y Gasset), lo que lo llevará a lanzar fogosas diatribas contra la sociedad conservadora, y sin hacer oídos sordos a esas mismas inquietudes que en lo social y en lo político lo incitaban a la actuación, sus aspiraciones humanistas, por otro lado, por muy loables que fuesen, apenas contaminaron el espacio íntimo de su obra poética, quedando como predicamentos marginales anclados a la esfera real de su yo público. Su universo poemático parece salvarse así de proyecciones ideológicas contundentes, necesarias para una vida mejor, pero empobrecedoras para el arte literario. En conexión con esto, no se le pasa a C. B. Morris por alto la idea de que Lo imprevisto, pese a la vicaria situación que lo pudo provocar, "no contiene amenazas, ni reconvenciones, ni lamentaciones; el poeta no cita ningún nombre, ni fecha, ni suceso comprobable. No aparece ningún enemigo, sino los sentimientos del enemigo, representados como una 'cloaca de desdenes', y no hay ninguna víctima excepto la libertad física" (1983: 30). Y para Martinón, el escritor transmutó su lamentable drama personal de encierro y de aislamiento físico en unos textos sometidos a un evidente control emocional y metafórico (1992: 283), atenuación del victimismo que nos lleva a subrayar la ambigüedad de una retórica que opera en el sistema intelectual y ético de López Torres: el divorcio entre su yo social y su yo privado, traslúcido e incontaminado de lo referencial, en sintonía con el plano imaginario, 
con sus figuraciones líricas. Poco puede sorprendernos, pues, que nos topemos con una obra que despunta, como observaron algunos, plagada de "mensajes de candor y gracia", si exceptuamos la moderada crudeza que resuman las composiciones compuestas en la cárcel. Dejando a un lado veladas insinuaciones a las duras penalidades de origen carcelario que pudieron afligirlo o su sátira de las instituciones del orden ("Obispos, concejales, militares y curas") en el "Poema de la langosta", la obra de López Torres es escasa en "urgencias políticas y sociales". El elemento sórdido, lo feo, en las contadas veces en que permean los endecasílabos de Lo imprevisto, encuentran un resquicio mínimo por el que desbordarse hacia otros estratos existenciales sublimados por la depuración metafórica. Pasajes como "la oscura cloaca de desdenes / insuficiente para tanta ofrenda / salta sobre la geometría de los bordes / inventando rizados carrouseles" (López Torres 1993: 88), con los que parece referirse el emisor poético a los retretes colmados de excrementos, introducen una nota de deformación de la realidad, de semblante desvaído tras ese barniz verborreico con que se representa el mundo de lo bajo y lo sucio.

Por los rieles de estas avenidas tortuosas, casi neobarrocas -si las comparamos con el laconismo y transparencia de Diario de un sol de verano- avanzan enmascarados los pocos poemas de este postrer volumen de 1936-37, publicado por el Seminario de literatura canaria de la Universidad de La Laguna en 1981. Obra póstuma de López Torres, como toda la de este artista y que, al margen de lecturas instigadas por el prisma analítico del surrealismo, cabe verla también como un homenaje a lo excremencial, al hombre vejado, a partir de una cosmovisión desasosegante del devenir cotidiano, tal como quiere deslizarse a través de las formas libres de versificación o con el corsé métrico del verso blanco licuado a través de imágenes inquietantes del tipo de las que Carlos Bousoño denominó "visionarias"16: "La emoción se colgaba de los ojos / y la sangre olvidando sus caminos / despertaba profundos cauces yertos" (López Torres 1993: 89); "[...] la fiebre dando saltos / asciende hasta el columpio azul del gozo" (1993: 85). Instrumentalizando los nuevos patrones subsumidos por el espíritu irreverente que promovían los exabruptos surrealistas, el libro de López Torres acierta a dar con una fórmula lindante con la extrañeza conceptual reterritorializadora de los estados alucinatorios de la existencia, una atmósfera de degradación, invadida de moscas y cloacas, un solar sembrado de tristeza, de opresión, de soledad, de hambre, de olores hediondos y de frustración sexual, impresiones subjetivas, pero colegibles y notorias, que son las que suscitan el alimento vulgar de la patata, el insistente revolotear de las moscas en torno al hábitat ocupado por el mirada silente del sujeto enunciador que observa quieto -y hasta con ternura- esos insectos, o esa cerrazón que ahoga de ecos fantasmales, de enrarecimiento, de obsesión y de inmundicia los estrechos contornos de una rutina erosionada por los efectos del calor y del sudor, sin el consuelo siquiera de una presencia femenina.

Llamó la atención a José María de la Rosa en su día (1983: 11) la madurez alcanzada en la mayoría de los textos que componen este título, al cotejar la violencia lingüística que transpira dicha propuesta con la mayor candidez de su poesía anterior. Ese sustancial incremento de la audacia, de lo extremo, de lo desagradable en la obra del malogrado artista, inclinación que lo avecina hacia una poética menos complaciente que la del Diario de un sol de verano, sobre el que a continuación nos detendremos, hace presagiar la enorme complejidad a la que hubiese podido llegar su producción de haber seguido transitando sin pausas, sin interrupciones y sobresaltos a lo largo del tiempo. Seguramente, de haber sobrevivido López Torres, su obra se hubiese hecho más grande, más influyente, y la eclosión de las vanguardias 
en las Islas, que, según la crítica, significó un “episodio”, un capítulo breve, pasajero, aunque rutilante, en la evolución de las letras canarias del siglo pasado, habría conformado un conjunto de páginas de mayor envergadura.

Aunque por distintas circunstancias, al igual que el autor de Lo imprevisto, J. A. de la Rosa, J. A. Rojas o Ernesto Pestana Nóbrega, entre otras voces jóvenes, murieron también pronto. No obstante, si bien toda esa generación de autores noveles quedó fracturada por el azote de la historia o por avatares del destino, el rápido paso de López Torres por las letras isleñas y por la vida en la primera mitad del siglo XX no aconteció en vano ni su temprana desaparición disminuyó su importancia como creador. Con independencia de los factores medioambientales, las investigaciones modernas que desde la década del setenta hasta la actualidad se han venido desplegando en torno a esta literatura de combate han sacado a la luz tanto la obra legada por López Torres como la producción de otras personalidades de no menor valía, algunas de ellas injustamente olvidadas ${ }^{17}$. Investigaciones como las de C. B. Morris, Miguel Pérez Corrales, Miguel Martinón, Salvador F. Martín Montenegro, Nilo Palenzuela o Andrés Sánchez Robayna, prologuista y anotador de la primeras ediciones de Lo imprevisto y de Diario de un sol de verano y co-editor de las Obras completas (1993) de López Torres, sin olvidar los precedentes de Ramón Feria y de Domingo Pérez Minik ${ }^{18}$, desvelan la inequívoca centralidad de nuestro autor en el insólito proceso de desarrollo y de asimilación -algo tardía pero intensa- de las modas surrealistas foráneas en el medio insular. En López Torres, cabe valorar, junto a su labor ensayística -que tampoco logró reunir en forma de libro- ${ }^{19}$, la fragmentación, la provisionalidad, el truncamiento y la dispersión orgánica. El número discreto de sus poemas no ha cesado de incrementarse con los años merced a la encomiable empresa de rescate realizada por los estudiosos arriba mencionados.

Si Lo imprevisto fue su último pulso con la poesía, Diario de un sol de verano es el primer empeño de organizar una obra de cierta coherencia. La edición de 1987 de este título se la debemos, lo mismo que la anterior, al esfuerzo de Sánchez Robayna. A semejanza de Lo imprevisto, este corpus poemático de juventud nos descubre un atractivo 'puzzle' de ingredientes sin un orden y un pulimento definitivos. Pero aquí, alejándose del pesimismo posterior, nos topamos con una amalgama de fragmentos con escenografía y motivos marinos, en la que el verso y la prosa, a la manera del Diario de un poeta recién casado (1917) de Juan Ramón Jiménez, de los Versos y estampas (1927) de Josefina de la Torre o de los Poemas a Mme. Josephine de Agustín Espinosa (redactados hacia 1929), logran armonizar con la dicción breve y la reacción contra el tipismo regionalista al uso, por mucho que persista sobre esa nueva entonación la interpretación de una geografía autóctona. Cabe calificar también de "inconclusa" dicha serie de textos, pero no tanto por el reducido número de poemas o textos prosísticos que lo componen (treinta y una piezas de escasas dimensiones), sino, como se encarga de señalar el profesor grancanario, por la fase prematura de redacción en que éstos se hallan, a pesar de las abundantes correcciones y enmiendas que adivinamos tuvo tiempo de introducir el autor antes de su encarcelamiento en 1936 (Sánchez Robayna 1987: 21).

El libro fue gestado en su mayor parte en el período estival de 1929, cuando la luz y el calor veraniegos arreciaban en la isla, sirviéndole dicha circunstancia de pretexto y de estímulo al autor. Dentro del marco topográfico de la isla, se vivifica la plasmación de una compleja red de tópicos -ahora con una visión fresca, renaciente- nucleados en torno a la idea muy insular de lo acuático; un mar de orilla similar al que se dibuja en Líquenes de García Cabrera o en Stadium (1930) de Ramón Feria. Las sensaciones estivales desencadenan un torrente cargado 
de teleología marinera que esmaltan de un brillo iridiscente las imágenes playeras invocadas, acciones insertas en espacios luminosos, en oleajes, en escenas donde reverberan los hilos refulgentes del sol y donde el agua oceánica ensaya un sinfín de movimientos, de espejismos tornasolados.

Imbuidos de una estructura diarística, como también el mencionado título de García Cabrera, los textos simulan ser obra y producto de un sol luminoso que se complace en hilvanar la trama del acaecer de los veraneantes, mientras permanece ajeno al tiempo de su caducidad. Sol que sube y baja, que evoluciona, que se desenvuelve como una pelota lanzada al aire observando ingenuo, desde huidizos y dinámicos ángulos espaciales, el trajín de los pescadores en sus faenas cotidianas, las variaciones climatológicas, el destino de una ola movediza, los juegos infantiles en la playa, la atmósfera cosmopolita del puerto, el adolescente despertar de la sensualidad y del cuerpo.

Si el género del diario asegura su estatus en el hecho de no ser más que una interpretación momentánea de la vida, lo mismo que la carta, la crónica y los anales, situando el fundamento de la dirección que toma el relato de la misma en el significado que tiene dicha existencia en el momento presente (cfr. Weintraub 21), al trasladarse ese protocolo al terreno de la poesía - no son frecuentes los diarios poetizados, otra rareza más del texto de López Torres-, las anotaciones hechas al vuelo inciden en la representación doblemente retórica del yo, "metáfora" (Olney 1972: 30-1, 34) o "desfiguración" (De Man 1991: 113118) del sujeto enunciador y del mundo que reordena el logos que se ficcionaliza. La doble retorización estriba, por un lado, en que asume, entre las diferentes jerarquías canónicas de los géneros literarios mayores, una forma consagrada (la poesía lírica) y, por otro, en que se vale de la prosopopeya como vehículo de canalización o mediador que subraya la estructura tropológica del discurso.

El sujeto al que se responsabiliza de los distintos pasajes no es otro que el astro diurno, personificado al contacto con este "mar de tierra" y de puerto íntimo y expansivo a la vez y en cuyas rocas los peces "dejan ocultos corazones / de piedras de colores" (López Torres 1993: 65). El sol está humanizado, y esa personificación -que proviene del hecho de que el emisor, en principio mudo e inerte, cobra voz y hegemonía en el poema, un sol que deambula a sus anchas por el paisaje costero retratado- es simultánea a la identificación del mismo objeto que se funde al alegre retozo de los humanos. La asociación de la estrella de fuego con los niños despreocupados en la arena resulta tan elocuente que, en el poema que encabeza el número dos, no puede evitar autodefinirse como un muchacho quinceañero: "Hoy, yo, moreno de quince años, me revuelco con los chicos en la playa hasta dejarlos dorados" (1993: 66). En el número ocho, es un miembro más de la pandilla: "Hoy, como la marea estaba vacía y la playa baja fuimos andando y resbalando en el musgo de las piedras y nos metimos en el puente" (1993: 69), cuando no se presenta como un simple acompañante de aquéllos o amigo cómplice: "Yo fui a la playa contigo, / ¿recuerdas?, yo fui a la playa. / Y te revolcó la ola, / a ti, que ibas conmigo, / ¿recuerdas?, a ti” (1993: 77). La infantilización solar, en sintonía con la entonación empleada y conectada al espíritu desenfadado de las criaturas cuyas pieles se broncean en sucesivas jornadas, corre paralela a la tentativa voluntaria de empequeñecimiento; el sol quiere igualarse a los otros, en una especie de conversión imposible que lo lleva a pintarse cosificado, como un instrumento lúdico más apto para que los demás lo manoseen, lo usen a su antojo: "Yo, pelota que me lanzan, / ¡ay!, los barcos” (1993: 67). Y lo mismo se desprende de lo que se expresa más 
abajo: "Volteo yo, pelota amarilla, / nueva" (1993: 67). Proceso dinamizador, de posible raíz dadaísta, el que describe el sujeto que verbaliza acentuado por medio de un esguince discursivo que se torna a ratos irónico en su cristalina ingenuidad, si bien se sitúa en las antípodas de esa "deshumanización" orteguiana supeditada al primer arte vanguardista. No hay más que considerar el fragmento del eclipse, donde la luna (en palabras del sol) "es una marquesa romántica tan pulcra y tan ceremoniosa que cuando me envuelve y me pierdo en sus enaguas almidonadas no puedo ni enfadarme" (1993: 68). O el juego fonético y semántico que abre el poema catorce: "Sal salada de sal, / agua morena" (1987: 39), cercano a las experimentaciones léxicas, de aires populares, de los que se nutren los poemarios de Alberti escritos en los años veinte.

La omnipresencia del mar, del cielo, de las algas, de la orilla bañada por las olas, fuerzas matriciales que sobresalen en cualquier entorno insular, enmarca el Diario de un sol de verano en un lugar próximo a la llamada poética "insularista" fomentada por la revista Cartones y que en la primera fase de su desarrollo tuvo su origen en Líquenes, el emblemático volumen de García Cabrera. Un artículo del autor gomero aparecido en el periódico La Tarde dos años después, "El hombre en función del paisaje" ${ }^{20}$, el mismo año en que sale el único número de Cartones, servirá de exponente definitorio a esta inquietud que aspiraba a romper con los convencionalismos regionalistas articulados a la decimonónica usanza para aventurarse, por el contrario, por una senda destinada a interpretar el paisaje canario confiriéndole connotaciones antinaturalistas. Semejante cosmovisión poética sería la piedra angular que articuló una forma de ver el arte fincada al mismo tiempo en el "cosmopolitismo" y en "lo isleño". El ensayo de García Cabrera incluía, entre otras reflexiones, la máxima de que "[l]a isla, para definirse, necesita -imprescindiblemente- del mar [...] nuestro arte debe construirse, esencialmente, con mar. Con espumas y con climas abisales [...]. Nuestro arte hay que elevarlo sobre paisaje de mar y montañas" (2005: 61-2). Y mar -o algunos de sus componentes adyacentes- es algo que no falta en este cuaderno de López Torres.

El sentimiento marinero fue uno de los temas idiosincrásicos sobre los que especuló Valbuena Prat para clasificar a los poetas canarios a partir del autor de Las rosas de Hércules, junto a otros asuntos como el aislamiento, el cosmopolitismo y la intimidad (2003: 56) -por lo tanto, repliegue, ensimismamiento y autocomplaciencia en conjunción con la actitud aperturista y con la extroversión del pensamiento-, una suma de rasgos dualísticos, contrapuestos que también reordena la lírica de López Torres, así como la de Félix Delgado, Josefina de la Torre o Ramón Feria, entre otros. Para el profesor barcelonés, en la interpretación del mar, se encuentra lo más interesante, lo más valioso, de la moderna poesía canaria, en concordancia con esa otra simiente, también muy canaria, que regurgita en la voluntad de permanecer abierto al exterior, postura universalista, desprejuiciada, que funciona como motor de innovaciones y antena receptora que sondea nuevas posibilidades creadoras.

No hay duda de que Domingo López Torres -lo mismo que otros poetas canarios (Tomás Morales, Domingo Rivero, Francisco Izquierdo, Pedro Bethencourt Padilla, Alonso Quesada, Saulo Torón y luego Julio Antonio de la Rosa, el mismo Pedro García Cabrera y muchos más) - comulgó con el acendrado sentimiento marinero, la pintura del mar tal como se divisa desde la isla y que, a la hora de redactar su Diario de un sol de verano y otras composiciones de fecha incierta, debió tener presente el programa insularista -que no está reñido con el influjo de lo universal- animado a finales de los años veinte por su amigo García Cabrera desde su poesía y sus ensayos críticos. En opinión de Ángel Sánchez, el mar en este 
volumen de López Torres, "más que propiciar la disolución metafórica del alma del poeta en el paisaje, lo que hace es producir una surgencia surreal de ensoñación pansensualista, aunque tierna, infantil” (1990: 27). Desde luego, es un mar entrañable, paradisíaco, jubiloso.

Bajo este prisma, brota espontáneamente la materia marina isleña seleccionada en los versos y en los poemas en prosa de Diario de un sol de verano -la familiar zona litoral frecuentada durante los meses estivales- entretejiéndose con el conglomerado de secuencias imaginísticas que anuda, eslabón a eslabón, el sueño de este universo poético. En la mayoría de los poemas, sin eludir un nítido enraizamiento con el paisaje cercano, propio y el predominio de una uniformidad temática, el mar, la costa y el puerto inmortalizados trascienden lo particular, lo concreto para universalizarse en su ansia de representación literaria. No en vano los versos esquivan la inclusión de la menor referencia topográfica al entorno geográfico inmediato en el que fueron concebidos. Se sugiere pero no se nombra. Tal vez en la abstracción de la experiencia recreada, en su esquemática representación, que rehúye de localismos fáciles, así como en los aires de folclorismo infantil y de sencillez, resida su mayor acierto.

Una aclaración. Aun empeñándonos en asociar los postulados de López Torres a la preocupación insularista en boga hacia finales de la década del veinte y principios de los años treinta, no se entendería su obra a carta cabal si la dejáramos desgajada de las arrolladoras vanguardias emergentes por el mismo período (expresionismo, futurismo, dadaísmo, cubismo y muy especialmente surrealismo). Todavía no se ha zafado de las garras de la "nueva literatura" (ultraísmo, purismo, neopopulismo...). Sin embargo, los movimientos innovadores y de ruptura -en concreto los de procedencia francesa, en los que López Torres hizo fecundas zambullidas-, seguidos de sus respectivas "traducciones" peninsulares e isleñas, hallarán en la creación del escritor canario una paulatina e inteligente acogida, aunque el autor siempre procesará esas técnicas a través del cedazo de su sensibilidad.

Todavía hacia 1929 es pronto para que esas lecturas de ascendencia foránea se aposenten en su imaginación, pero ya a sus diecinueve años la retórica inconformista del cambio empieza a explorar nuevas vías y, de hecho, algunas de las imágenes con las que trabaja en composiciones de esta época declaran una tímida deuda con las inquietudes expresivas que están renovando las letras internacionales. Piénsese en las alusiones al mundo del deporte o del cine o en la poetización de la máquina, que nos recuerdan el espíritu modernizador del futurismo: "El mar: stadium / de profesionales internacionales, / de entrañas dinámicas" (López Torres 1993: 67); “yo, como los artistas cinematográficos, no almuerzo” (1993: 66)²1; "los peces del mar / son aeroplanos del cielo" (1993: 75). El estilo pictórico de los cubistas se difumina tras la cortina de humo de las formas geométricas organizadas para canalizar la realidad fragmentada en el texto número cuatro: "Se descomponen / cuerpos duros de montañas / en triángulos biselados" (1993: 67), mientras que otras propuestas métricas remiten a las fantasías "aberrantes", nacidas en el inconsciente, los "retorcidos pensamientos" y las "subterráneas alcantarillas", según expresiones de López Torres (1993: 168), que años atrás había puesto en el punto de mira el psicoanálisis y que, por obra y gracia de algún demonio burlón, afloran en la práctica de la écriture automatique: "[...] jugando con las niñas / de nuestros ojos / a las cuatro esquinas", nos dice en el poema vienticuatro (1993: 78).

No obstante, este acercamiento a la fuente del inconsciente acontece de momento en forma embrionaria, pues las compuertas del automatismo psíquico, que instalaría al escritor en un estado más próximo al sueño que a la vigilia, se cierran en la poesía de López Torres antes de que el mundo de la lucidez se pliegue al cien por cien a los perímetros de la realidad, 
antes de que el control sobre las ideas objetivas entre en completa crisis. Las estridencias, los excesos y las extralimitaciones de la literatura transgresora de las vanguardias amortiguan su impacto en su obra más avanzada bajo el poder de otros influjos, como el de la poesía lorquiana y de los aromas líricos de la poesía neopopular andaluza -verbigracia, la de Alberti, otro de los poetas de la "generación del 27" que, junto a Lorca, se suma a la escasa lista de autores españoles venerados por el poeta canario-. La incidencia literaria del poeta granadino en la estética del escritor tinerfeño es bien palpable en el simbolismo del color verde, del mismo modo que se reconoce en el tono popular que traspasa algunas composiciones tempranas: "Voz verde de tu mirada. / Vena del monte. / Mancha primera del agua. / Menta de la fruta agria" (1993: 70) ${ }^{22}$. En cambio, la huella del autor gaditano puede columbrarse, amén de en la misma vertiente popular de sus versos o en la complacencia por los escenarios costeros, en un similar desplazamiento de motivos seráficos que remiten insoslayablemente no sólo a una de las preferencias temáticas del autor de Sobre los ángeles, sino ocasionalmente a Federico García Lorca -la literatura y el arte han hecho de la figura del ángel un icono universal de múltiples lecturas, entre las que no se descarta, como en el caso de Lorca, la alusión a la sensibilidad gay a la que se adscribe el poeta del Romancero gitano-, o incluso evocan al Juan Ramón Jiménez de Poesías escojidas (1917) y de la Segunda antolojía poética (1922), quien nos hablaba ya de unos "Vagos ánjeles malvas / (que) apagaban las verdes estrellas" (1991: 75).

Como motivos literarios, no todos los ángeles son homologables. Indica Juan Eduardo Cirlot que el ángel es "(s)ímbolo de lo invisible de las fuerzas que ascienden y descienden entre el origen y la manifestación” (2006: 82). Y agrega Pérez-Rioja que para el cristianismo son "mediadores entre el cielo y la tierra, entre Dios y los hombres" y que de ellos "se sirve el Creador para hacer cumplir en la tierra sus designios" (1971: 65). Pero sobre esa vaga simbología de cariz místico que emana de las formas angelicales, se apacienta una escala de matices tornasolados que variará dependiendo del enunciado en el que intervenga o de los atributos y calificativos que le asigne el autor a estas figuras. A diferencia de las estampas de querubines pintadas por sus colegas andaluces, las entidades espirituales que agrupó López Torres aparecen unas veces como seres que denotan una variedad semiológica que les imprime un sentido ambiguo en sus roles, pero que en nada augura la visión inquietante de esos otros "arcángeles dormidos" que encontraremos posteriormente invocados en el poema sexto de Lo imprevisto:

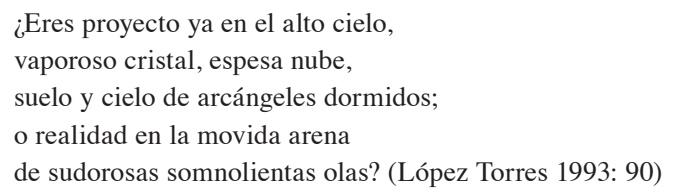

En la obra de su compañero de oficio Emeterio Gutiérrez Albelo, la presencia del ángel destila mayor dramatismo: está marcada por lo sangriento y la involuntaria crudeza, pues en vez de salir airoso de la operación a la que es sometido, acaba desplumado, hecho pedazos por las manos inexpertas del hablante lírico:

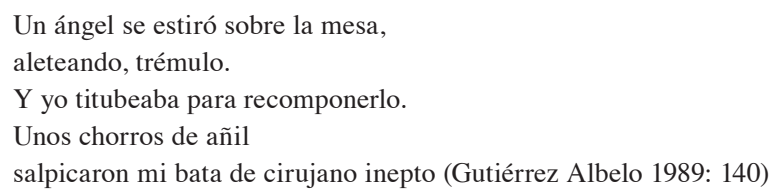


Contrariamente a esta vertiente de surrealismo negro, los ángeles de Diario de un sol de verano son inocentes marionetas extraídas de un teatro de guiñol: "Y ángeles cristalizados / colgaban desde las nubes / amarrados por las alas" (1993: 70), seres semidivinos que portan fuertes dosis de voluptuosa sabiduría: "Tus formas luminosas, / llenas de claridad y ángeles sabios" (1993: 73), o, en fin, enamorados pilluelos prendidos caprichosamente al cuerpo de un/a interlocutor/a o a las siluetas de esos niños felices que avanzan hacia la edad adulta apenas rompen el cascarón de la adolescencia: "Tus caderas tan claras / de luz y sombra / tienen perdido a un ángel / con alas rotas (1993: 73).

Humanos, demasiados humanos, estos perfiles de Diario de un sol de verano protagonizan un hechizo conceptual anclado en una aparente intranscendencia ontológica cifrada en moldes poéticos sencillos. Los versos se rellenan de elementos anecdóticos, en ocasiones narrativos que dotan de una expresión verbal breve, concisa y de una sospechosa simplicidad a un discurso donde lo irónico roza con la sutil indiferencia y con la personificación de ingredientes naturales, y donde la hondonada del mar, invariablemente el mar, aparece como trasfondo de ensueño que delinea los trazos impresionistas de todo ese universo marinero. El mar, planicie ondulada, movible y de horizontes difusos, según puede apreciarse desde ciertos puntos de la costa, como afirmó uno de los compañeros de andanzas literarias de López Torres, Pedro García Cabrera, el teórico del insularismo, recorta la isla, la "estrangula", a-islándola de su entorno global y enroscándola en sí misma como una caracola encantada (2005: 52).

Diario de un sol de verano convierte en remembranza emotiva una experiencia alegre, inconsciente, atada a una niñez embadurnada de algas, de salitre, saciada a base de juegos interminables, llena de travesuras en la arena, eterno paraíso de la infancia, al fin y al cabo, y de los veraneantes, edén perdido -instantáneamente recobrado a través de la magia poéticaque entronca el sentimiento del mar, de los barcos del puerto, de los alisios, del paisaje litoral con el milagro de la vida antes de su acabamiento nocturno. Un enclave privilegiado con un decorado que -es fácil sospecharlo- es el mismo que nutrió la propia niñez del escritor. En estos poemas, no hay nada que vaticine, que ni siquiera adelante, el purgatorio de abandono y exterminio que atenaza a la existencia insular, la "isla de las maldiciones" que bautizara Agustín Espinosa, ni el trágico desenlace que aguardará al poeta ocho años después, cuando las fuerzas falangistas que se apoderan de Tenerife en 1936 decidan quitar de en medio una personalidad inconformista como la suya, animada por el vertiginoso ritmo de la poesía y henchida de iniciativas culturales y de reivindicaciones sociales que no tenían cabida en el nuevo orden que se quería imponer. Por su rebeldía, se decide domesticar el cuerpo del poeta, acallar su espíritu, enterrarlo en el mar santacrucero, un mar cenital, mortuorio y febril -"mares del silencio", "mares petrificados, aguas turbias"- que amenaza con liquidar la placidez evocada en Diario de un sol de verano, un poemario que se sitúa en el centro de la empresa inaugural que recupera la utopía de un paraíso clausurado y que, junto a otras composiciones menores de López Torres -“En el puerto", "El marinero y la novia", "Se vende 'La Esperancita", "Diles que tú quieres ir" o "Las cuerdas del barco"-, desdice la supuesta tendencia, apuntada por Valbuena Prat en su Historia de la poesía canaria, que dividiría a los vates de las dos islas mayores del Archipiélago (Gran Canaria y Tenerife) en polos diametralmente antagónicos: mientras los de la isla occidental vivirían tierra adentro, dando la espalda al mar, los poetas de Gran Canaria lo cantarían con mayor vehemencia, enfocando su expansiva mirada hacia el horizonte oceánico (2003: 28). Si bien, en líneas generales, esa distinción la refrendan empírica y hasta históricamente numerosos poemas 
compuestos desde el siglo XVI hasta el Romanticismo, no es una invariante inapelable. Son demasiadas las salvedades, demasiados los hibridismos -sobre todo en el siglo XX-como para que tomemos como una regla de oro esa dogmática diferenciación académica. Una de esas excepciones nos la ofrece la poesía de López Torres, que gusta del mar abierto, de las zonas portuarias, que se mantiene porosa al efecto de la aureola mágica del agua, a su ensoñación y a su cosmopolitismo reinante. Un mar de mediodía que devendrá, a la postre, mar de medianoche.

\section{Notas}

1. Más poéticamente lo expresó Pérez Minik: “esta facción española surrealista de Tenerife buscó siempre su fuente en el mismo nacimiento del río", añadiendo a renglón seguido que "(l)as traducciones se hacían en la isla, se leían todas las revistas de la escuela, se discutía hasta el amanecer los problemas palpitantes, los literarios, los políticos, los morales, la propaganda, la conducta cotidiana" (1995: 61).

2. Para un conocimiento mejor de la obra de Espinosa, véanse los estudios de Pérez Corrales (1986, 1998). La aparición de Romanticismo y cuenta nueva de Gutiérrez Albelo y de Transparencias fugadas (1934) de García Cabrera también fue saludada por López Torres en una nota publicada en La Tarde el 19 de diciembre de 1934.

3. “Tus ojos glaucos” apareció en el número 28 de la publicación, correspondiente al 11 de julio de 1926 , y "En el puerto" en el número 117, el 17 de abril de 1928.

4. Concretamente, el 28 de febrero de 1928.

5. Así se describieron algunos de sus primeros mentores en un manifiesto aparecido dos años antes en las páginas de La Gaceta Literaria, dirigida por Giménez Caballero (nº 36, 15 de junio de 1928).

6. Dichos textos son los siguientes: "Ahora te vas, ahora vuelves / ¡saltas! / Por debajo de ti misma / van pasando las palabras. / -Ahora te vas, ahora vuelves- / Los azules, a tres tiempos / -'por un caminito / cansado de andar'-, / cantan. / Mira cómo caen al mar / collares de cuentas blancas". "Cuando la ola se marcha / ¡ay! que me arrastra y me lleva. / Ola, ¿te quieres estar quieta? / Y me dejan en la boca / lágrimas de agua perdida. / Cuando pasas de ti a mí / ¡ay! que te quedas sin ti, / sola, de sal, en la arena". Ambos textos compartieron página en la misma revista con poemas de Carmen Jiménez ("Montañas") y de Pedro García Cabrera ("Pitera"). La mención a elementos paisajísticos isleños es el común denominador de estos textos, pues los animadores de Cartones entiendieron que la peculiar geografía de las islas moldea en el ser isleño una específica espiritualidad.

7. De hecho, los primeros números de Gaceta de Arte dieron cobijo a "los abstractos alemanes", al postimpresionismo y al nuevo constructivismo, así como a la arquitectura racional, tendencias que $a$ priori eran definidas por oposición al surrealismo.

8. Otros dos incitantes que menciona Pérez Minik en la recepción del surrealismo fueron el triunfo de la Segunda República, con lo que supuso de renovación tanto en la ideología (defensa de un pensamiento nuevo dentro de una democracia muy pluralista) como en el arte (compromiso literario que tendía a alimentarse de lo mejor que procedía de otros países), así como los desplazamientos de Eduardo Westerdahl, futuro director de la Gaceta, por Centroeuropa (Holanda, Checoslovaquia, Alemania, Francia), donde se empapó de la plástica, la arquitectura y la poesía modernas (2004b: 74-5). 
9. Con anterioridad, en diciembre de 1928, el artista lagunero había expuesto ya en la capital tinerfeña, en el Círculo de Bellas Artes, algunos de sus primeros cuadros, aunque insertos aún dentro de un cubismo mimético y epidérmico, y acompañados de los de la pintora francesa Lilly Guetta. Piénsese que la etapa propiamente surrealista de Domínguez no comienza hasta 1929. En otra exposición colectiva que estuvo abierta al público entre el 18 y el 31 de diciembre de 1932 -de nuevo en el Círculo de Bellas Artes de Santa Cruz de Tenerife-, lo mismo que en la muestra de mayo del 33, se exhibieron ya pinturas inscritas dentro de un surrealismo de órbita dalianiana.

10. La propuesta de sondear en las oscuras regiones de la psique para construir una "segunda realidad" que subsiste paralelamente a la realidad ordinaria pero que no ha de ser confundida con ésta es uno de los bastiones en los que abunda la crítica sobre el surrealismo. Arnold Hauser, a mediados del siglo pasado, esclarecía con cierto recelo que "(l)os surrealistas esperan la salvación del arte, del cual reniegan tanto como los dadaístas, y al que aceptan a lo sumo como vehículo del conocimiento irracional, de sumergirse en el inconsciente, en lo prerracional y lo caótico, y adoptan el método psicoanalítico de la libre asociación, es decir, del desarrollo automático de las ideas y de su reproducción sin ninguna censura racional, moral ni estética, porque imaginan que con ello han descubierto una receta para la restauración del bueno y viejo tipo romántico de inspiración” (1969: 284).

11. La exposición se desarrolló en el Ateneo de Santa Cruz de Tenerife entre los días 11 y 24 de mayo de 1935.

12. Fue muy grande el impacto de le produce a Breton la visita al Teide, poéticamente evocado luego en "El castillo estrellado", capítulo V de L'amour fou (1937) (cfr. Breton 2003: 17-37).

13. Respecto a la entusiasta lectura de Hans Arp por parte de López Torres, véase el artículo de Nilo Palenzuela (1997). El poeta tinerfeño no sólo escribió agudos comentarios sobre la obra escultórica del artista franco-alemán, sino que agregó en el mismo número de la Gaceta de Arte (nº 24, marzo de 1934) el poema titulado "L'air est une racine", traducido al castellano seguramente por el propio López Torres.

14. Recuérdese que "La revolución ante todo y siempre" es uno de los primeros manifiestos que publicaron los surrealistas en 1925.

15. La exploración en las ensoñaciones sexuales se revela en sus últimas composiciones: así en el primer poema de Lo imprevisto -“(Dominando la muchedumbre de deseos / hay una estatua fálica que indica / caminos para idéntico destino.)" (López Torres 1993: 86)- o en el titulado "La patata": "El filo más agudo del deseo, / de mi sangriento amor, mi ruin coraje, / te arrancaba la piel entre mis dedos [...]" (1993: 87).

16. Se distingue la imagen visionaria de la metáfora tradicional (la utilizada desde la Antigüedad hasta finales del Romanticismo) en no presentar término real o en no existir una relación entre el término real y el término imagen basada en una semejanza objetiva (física, moral o de valor), perceptible por la razón. La imagen visionaria hace que nos emocionemos sin que nuestra razón conozca ninguna semejanza lógica entre los objetos real e imaginario, "basta con que sintamos la semejanza emocional entre ellos. Se trata [...] de una imagen irracional y subjetiva" (Bousoño 1985: 195).

17. Miguel Martinón (1996a: 13-40) ha repasado la tradición crítica e historiográfica sobre las vanguardias en Canarias desde mediados de los sesenta -con una mención especial a dos títulos anteriores: Signos de arte y literatura 1936) de Ramón Feria y la Antología de la poesía canaria, I. Tenerife (1952) de Domingo Pérez Minik- hasta principios de los noventa.

18. Además de su famosa Antología de la poesía canaria, Pérez Minik publicó en 1975 su libro sobre el grupo surrealista de Tenerife. 
19. Tenía en mente publicar un libro sobre el surrealismo que nunca llegó a cristalizar.

20. Este artículo, dividido en varias entregas, vio la luz los días 16, 17, 19 y 21 de mayo de 1930.

21. Los surrealistas sintieron también verdadera pasión por el séptimo arte a cuyo nacimiento y desarrollo asistieron expectantes. A pesar de que en la obra de López Torres la interdiscursividad de la literatura y el cine es bastante limitada, y en nada comparable a la que se produce en la obra de sus contemporáneos Emeterio Gutiérrez Albelo y Agustín Espinosa, el poema inédito "Escándalo", localizado por Roberto García de Mesa (2008: 640), prueba esa relativa influencia. "Escándalo" evoca las salas de cine como un locus en el que se desata un erotismo censurado por la moral burguesa. Aprovechando la oscuridad de estos lugares, una pareja de enamorados se entrega a sus instintos sensuales. En el texto, no recogido en el volumen de las Obras completas de 1993, la realidad de la sala se confunde con la ficción mostrada en la pantalla al mezclarse en la imaginación del hablante poético (masculino) la imagen de la mujer que está con él con la de la actriz de la película que se proyecta, posiblemente la comedia Kiki (1932), un film protagonizado por la estrella polaca Anny Ondra y que se entrenó en el cine Royal Victoria de Santa Cruz de Tenerife el 22 de abril de 1933.

22. En el manejo de formas tradicionales como el romance, también se advierte cierto ascendente lorquiano. Véanse los poemas de López Torres, ajenos a Diario de un sol de verano, "El jinete en la montaña", "El marinero y la novia", "Se vende 'La Esperancita"” o "Diles que tú quieres ir".

\section{Bibliografía}

Baudelaire, Charles. 1995. El pintor de la vida moderna. (Trad. de Álvaro Rodríguez Torres). Bogotá: El Áncora Editores.

Bousoño, Carlos. 1985. Teoría de la expresión poética. Vol. I. (7ª ed. aum.). Madrid: Editorial Gredos.

Breton, André. 2003. El viaje a Tenerife. Sel. de Alfonso González Jerez. Prol. de Antonio Álvarez de la Rosa. Santa Cruz de Tenerife - Las Palmas de Gran Canaria: Ediciones Idea.

Cirlot, Juan Eduardo. 2006. Diccionario de símbolos. (10 a ed.). Madrid: Ediciones Siruela.

García Cabrera, Pedro. 2005. “El hombre en función del paisaje”. En: Rodríguez Padrón, 49-63.

García de Mesa, Roberto. 2008. "Las vanguardias literarias y el cine en Canarias: 'Escándalo', poema inédito de Domingo López Torres". Estudios Canarios. Anuario del Instituto de Estudios Canarios. 50-51: 631-42.

Gutiérrez Albelo, Emeterio. 1989. Campanario de la primavera. Romanticismo y cuenta nueva y Enigma del invitado. Introd. de Ernesto J. Rodríguez Abad. Islas Canarias: Viceconsejería de Cultura y Deportes del Gobierno de Canarias.

Hauser, Arnold. 1969. Historia social de la literatura y el arte III. Naturalismo e impresionismo. Bajo el signo del cine. (Trad. de A. Tovar y F. P. Voras-Reyes). ( $3^{\mathrm{a}}$ ed.). Madrid: Ediciones Guadarrama. 
Hernández, Domingo-Luis (ed.). 2006. Surrealismo Siglo 21. Islas Canarias: Gobierno de Canarias.

Jiménez, Juan Ramón. 1991. Segunda antolojía poética (1898-1918). Ed. de Jorge Urrutia. (7ª ed.). Madrid: Editorial Espasa-Calpe.

López Torres, Domingo. 1993. Obras completas. Ed. C. B. Morris y Andrés Sánchez Robayna. Santa Cruz de Tenerife: Aula de Cultura del Cabildo Insular de Tenerife.

Man, Paul de. 1991. "La autobiografía como desfiguración". Suplementos Anthropos: La autobiografía y sus problemas teóricos. Estudios e investigación documental. 29: 113-18.

Martinón, Miguel. 1992. “La poesía de Domingo López Torres”. En: Sánchez Robayna (ed.), 265-87. 1996a. “La recuperación de la literatura vanguardista canaria”. En: Martinón (1996 c), 13-40. 1996b. "Domingo López Torres y la poesía insular de su tiempo". En: Martinón (1996c)., 105-19.

1996c. La escena del sol (Estudios sobre poesía canaria del siglo XX). Las Palmas de Gran Canaria: Ediciones del Cabildo Insular de Gran Canaria.

Morris, C. B. 1979. “El surrealismo en Tenerife”. Revista Iberoamericana. 45 (106-107): 343-49.

1983. “Domingo López Torres bajo el imperativo de su época”. Syntaxis. 3: 18-35.

2000. El Surrealismo y España, 1920-1936. (Trad. de Francisca Escribano). Madrid: Espasa Calpe.

Olney, James. 1972. Metaphors of Self. The Meaning of Autobiography. Princeton: Princeton University Press.

Palenzuela, Nilo. 1992. "El proceso de las revistas: de 'La Rosa de los Vientos' a 'Índice”.. En: Sánchez Robayna (ed.), 19-38.

1997. “Domingo López Torres, Hans Arp y el surrealismo". Revista de Filología de la Universidad de La Laguna. 15: 189-203.

Paxton, Robert O. 2005. Anatomía del fascismo. (Trad. de Manuel Álvarez Flórez). Barcelona: Ediciones Península.

Pérez Corrales, Miguel. 1982. "Historia documental del surrealismo en Canarias (1930-1936)". En: Segura Clavell et al., 665-741.

1986. Agustín Espinosa, entre el mito y el sueño. Las Palmas de Gran Canaria: Cabildo Insular de Gran Canaria. 
1998. Entre islas anda el juego (Nueva literatura y surrealismo en Canarias, 19271936). Teruel: Museo de Teruel.

2006. “Romanticismo y surrealismo”. En: Hernández (ed.), 18-43.

Pérez Minik, Domingo. 1995. Facción española surrealista de Tenerife. Tenerife - Madrid: CajaCanarias-Ediciones La Palma.

2004a. “La condición humana del insular”. En: Pérez Minik (2004c): 45-60.

2004b. "Reto y propuesta de Gaceta de Arte". En: Pérez Minik (2004c): 73-82.

2004c. Isla y literatura. Introd. de Rafael Fernández Hernández. Vol I. Santa Cruz de Tenerife: CajaCanarias

Pérez-Rioja, José Antonio. 1971. Diccionario de símbolos y mitos. Las ciencias y las artes en su expresión figurada. $2^{\text {a }}$ ed. Madrid: Editorial Tecnos.

Rodríguez Padrón, Jorge (comp.). 2005. El hombre en función del paisaje y otros ensayos. Santa Cruz de Tenerife: Caja Canarias.

Rosa, José Ma de la. 1983. “Perfil y recuerdo de Domingo López Torres”. Jornada Literaria. 03/12: 11.

Sánchez, Ángel. 1990. “Introducción”. En: Domingo López Torres. Obra selecta, 11-33.

Sánchez Robayna, Andrés. 1987. “Esta edición”. En: Domingo López Torres. Diario de un sol de verano, 21.

1992a. "Para la historia de una aventura: las vanguardias históricas". En: Sánchez Robayna (ed.), 3-17.

(ed.). 1992b. Canarias: Las vanguardias históricas. Santa Cruz de Tenerife: Centro Atlántico de Arte Moderno-Viceconsejería de Cultura y Deportes del Gobierno de Canarias.

Segura Clavell, José et al. 1982. Homenaje a Alfonso Trujillo. Arte y arqueología. Vol I. Santa Cruz de Tenerife: Aula de Cultura del Excmo. Cabildo Insular de Tenerife.

Torre, Guillermo de. 2001. Historia de las literaturas de vanguardia. Madrid: Visor Libros.

Valbuena Prat, Ángel. 2003. Historia de la poesía canaria. Santa Cruz de Tenerife - Las Palmas de Gran Canaria: Ediciones Idea.

Weintraub, Kart J. 1991. “Autobiografía y conciencia histórica”. Suplementos Anthropos: La autobiografía y sus problemas teóricos. Estudios e investigación documental. 29: 18-33. 
